\title{
Adoption and Utilization of ICT Through Farmers.NG Technology in Ondo State, Nigeria
}

\author{
Felicia Itunnu Wole-Alo ", Inioluwa Oluwaseun Oluwagbemi \\ Department of Agricultural Extension and Communication Technology, Federal University of Technology, Akure, Nigeria
}

\section{Email address:}

fellymee@yahoo.com (F. I. Wole-Alo)

${ }^{*}$ Corresponding author

\section{To cite this article:}

Felicia Itunnu Wole-Alo, Inioluwa Oluwaseun Oluwagbemi. Adoption and Utilization of ICT Through Farmers.NG Technology in Ondo State, Nigeria. International Journal of Applied Agricultural Sciences. Vol. 6, No. 1, 2020, pp. 7-15. doi: 10.11648/j.ijaas.20200601.12

Received: February 1, 2019; Accepted: April 8, 2019; Published: February 4, 2020

\begin{abstract}
The study examined the Adoption and Utilization of ICT through Farmers.Ng Technology in Ondo State, Nigeria. A total of 86 respondents were used for the study; which were farmers who are registered with the company (farmers.ng) in Ondo state which were selected through Multi-stage sampling procedure. The socio-economic characteristics respondents revealed that majority $(73 \%)$ of them were male. The mean age of the farmers was 51 years. Most $(77 \%)$ of them were married, majority (69\%) were Christians, a substantial majority (48\%) had primary education, $62 \%$ of the respondents engaged in farming as their primary occupation and $61 \%$ had no secondary occupation. The average monthly income of the respondents was $\$ 58209$; the average household size was 5 and $59 \%$ of the respondents were members of crop societies. The results of the hypotheses indicated that there was significant relationship between the socioeconomic characteristics and the adoption of the market solution technology. It also showed that there was significant relationship between the attitude of the respondents and the utilization of the market technology. Study recommends that the use of ICT should be facilitated amongst farmers by national governments and development partners to facilitate sharing of agricultural related information, knowledge and experiences.
\end{abstract}

Keywords: Adoption, Utilization, ICT, Farmers.Ng and Technology

\section{Introduction}

Poor access to markets and marketing information has made rural farmers vulnerable to exploitation by off takers in the chain. Rural farmers most times don't know the prices of their produces at distant markets. Middlemen also known as off takers visit the farmers at their homes and local markets to purchase their goods. In most cases, farmers negotiate based on the prices proposed by the middlemen. Middlemen cheat farmers by taking advantage of their lack of knowledge of market prices, poverty and weak bargaining power arising from illiteracy and low social status [9]. Intermediaries often flout market norms and their pricing lacks transparency [16]. Farmers' markets access is limited by costs (in terms of time and resources), lack of information and poor knowledge of marketing. The use of information and communication technologies (ICTs) is one approach to linking smallholder farmers to markets. The recent developments of ICTs have completely changed the way people communicate, share information and do their businesses. ICTs have emerged as an important instrument in bridging the information gap. ICTs (especially mobile phones) link farmers to markets and provide them with current market information. Based on the information, farmers can perform informed decision-making during selling and when farming. NGOs and farmers' organizations may get involved in linking farmers to markets and in helping them to use current technologies in their farming activities [12]. Availability of agricultural information and effective use in imperfect markets can be considered as a merit good. It will make market segments more contestable and it will make farmers more eager to develop commercial activities if the information is adapted to their needs. The existence and timely use of reliable information on prices, quality, supply and market demand conditions contribute to ensuring a better market environment and to balance the capacities of the various actors [2]. 


\subsection{Farmers.ng Market Solution Technology}

The farmers.ng market solution technology is a new technology that provides farmers information such as name, type of crop cultivated, location and telephone number to buyers of their product in the urban areas. This technology eliminates the activities of middle men who rip farmers off their maximum profit. Also it has been noticed that rural farmers are not well informed of the standard market prices of agricultural products. This lack of information has deprived the rural farmers of negotiation power and they tend to accept the offers presented to them by the aforementioned middle men [1]. Although in some other cases, the lack of storage facilities pressures the rural farmers to sell their products without considering the price offer due to fair of spoilage. Rural farmers do not only lack information about standard market prices of agricultural products but also lack information about different opportunities that can improve their agricultural business and standard of living as a whole [4].

The market solution technology is of great importance to the better livelihood of farmers. Some of the importance is listed as follows:

a. Elimination of middle men activities thereby linking farmers directly to urban market.

b. Provision of adequate market price to rural farmers; this help the farmers to know how best to sell their produce to maximize profit.

c. Improvement of the livelihood of rural farmers.

d. Gives farmers control of market prices of farm produce.

e. Provides other meaningful opportunities to farmers.

f. Makes it easier for buyers of farm produce to locate the nearest farmer who has the crop in demand.

g. Provides ready market for products.

h. Reduces spoilage of farm produce because the products don't stay long before they are sold.

\subsection{Operation of Farmers.ng Technology}

This involves the way the market solution technology is being operated. It is a simple process that involves the registration of farmers using their names, type of crop planted, size of farm land, location of the farm and telephone number. The farmers are then trained and given the company's crop catalogue that contains the designated code for each crop which is to be texted to the organization number when the crop is ready for harvest. Once the message is received from the farmer, the details of the farmer is then put on the official website of the organization where buyers of such crop can pick any farmer's details that suit their needs and negotiate with the farmer [4].

\subsection{Problem Statement}

With a staggering population of over 170 million of Nigeria, over $70 \%$ of the population lives in the rural areas with farming as their main source of livelihood. However this large population of farmer still lives in abject poverty due to lack of access to the market to sell their farm produce and lack of access to market information that could be of importance in their decision making. These smallholders depend on traditional means of communication and sell their produce at the farm gate and local markets [11]. This has not been fruitful for these poor farmers as traders, intermediaries and other stakeholders in the chain take a large share of their produce. As a result, rural farmers remain poor and agriculture contributes little to their income, economy and welfare. The use of information and communication technologies (ICTs) is one approach to linking Smallholder farmers to markets. ICTs link farmers to markets and provide them with current marketing information. An example of one the ICT platforms in Nigeria that help connect smallholder farmers to market and provide them with market information is farmers.ng a technology start up that hopes to improve the lives of farmers who are registered with the company. There is a gap between the farmers and their access to ICT in the study area which needs to be filled urgently and it is against this background that this research is designed so as to answer the following research questions:

a. What are the socio-economic characteristics of the respondents?

b. What is the level of utilization of the market technology amongst the respondents?

c. What is the attitude of the respondents towards the market technology?

d. What is the effect of the market technology on the income of the respondents?

e. What are the constraints attached to the usage of the market technology?

\subsection{Objectives of the Study}

The broad objective of the study to Assess the Adoption and Utilization of Farmers.Ng Market Technology by Rural Farmers in Ondo State, Nigeria. The specific objectives are to:

1. Ascertain the socio-economic characteristics of the respondents in the study area.

2. Determine the level of utilization of the market technology amongst the respondent in the study area.

3. Determine the effect of the market technology on the income of the respondents.

4. Assess the attitude of the respondents towards the market technology.

5. Identify the constraints to the usage of the technology by the respondents.

\subsection{Research Hypotheses}

$\mathrm{Ho}_{1}$ : There is no significant relationship between the adoption of the market technology and socioeconomic characteristics of the respondents.

$\mathrm{Ho}_{2}$ : There is no significant relationship between the attitude of the respondents and the utilization of the market technology.

\section{Methodology}

The study was carried out in Akure South Local 
Government Area and Owo L. G. A of Ondo State of Nigeria, due to its well-known agricultural activities. The state is located at latitude $7^{\circ} 40^{\circ} \mathrm{N}$ and longitude $5^{\circ} 15^{\prime} \mathrm{E}$ and is mainly an upland zone (above 250 meters above sea level). Purposive sampling technique was used for the study. This depicts that the respondent was picked based on researcher's judgment. The proposed respondents were farmers in Akure South Government of Ondo state who are registered with the company [4] and who has been educated on the market solution technology. A total of eighty six (86) respondents registered under the ICT initiative being implemented were selected for the study. First Stage involved the Purposive selection a local government area out of eighteen local government areas in Ondo state while the second stage involved random selection of eighty six (86) respondents from a list of registered farmers in the chosen local government area (Akure south). The random selection of the respondents included respondents met in the area during the data collection. The data was collected through the use of well-structured questionnaire.

\section{Results and Discussion}

\subsection{Socio-economic Characteristics of Respondents}

Table 1 reveals that $73 \%$ of the respondents were male while $26 \%$ were female this implies that farming activities is still being dominated by male in the rural communities. This corroborates the findings of other authors that male headed households are predominant in the south west of Nigeria [6]. Findings in Table 1 reveal that $19 \%$ of the respondents were below 40 years while $15 \%$ were within the age of $41-45$ years, $11 \%$ were between the age of $46-50$ years, $9 \%$ within 51-55 years, 23\% within 56-60 years and 23\% above 60 years. The mean age of the respondents was 51 years. The respondents are more likely growing past their active years, $67 \%$ were below 51 years. This finding implies an ageing farming population, which corroborates the findings of other studies $[15 ; 10]$. Results in Table 1 show that majorities (77\%) of the respondents were married while $8 \%$ were single, $5 \%$ were divorced, $4 \%$ were separated and $7 \%$ were widowed. This finding further buttresses the fact that they had large household sizes as only the married can have households. The Table also reveals that $69 \%$ of the respondents practiced Christianity while $30 \%$ practiced Islam and $1 \%$ practiced other religion which is perceived to be traditional religion. This indicates that Christianity was the religion mostly practiced in the study area. This finding is not in support of [3] who found out that a substantial percentage of respondents in the study area were Muslims.

Findings from Table 1 show that majority (48\%) of the respondents only went to primary school while $22 \%$ went to secondary school. Only $5 \%$ had tertiary education while $24 \%$ of the respondents had no formal education. This indicates that majority of the farmers in the study area had primary formal education therefore there might be higher likelihood for fast adoption of technology. This reveals the fact that majority of those in the rural areas are either without formal education or only with primary education which enables them to only read and write. This is in line with the findings of [5] who found out that majority of the farmers have primary education which enables them to only read and write. The educational level of the farmers can determine the adoption and level of utilization of technology especially if ICT related. Findings from the Table show that majority $(65 \%)$ of the household of the respondents were within 4-6 household size, $11 \%$ were below 3 while $24 \%$ had household size above 6 . Farmers in this region are likely to have access to family labour. This finding is also in line with other studies that indicated large of household sizes of 4-6 persons per house in the rural areas of south west Nigeria [18].

Findings in Table 1 reveal that $62 \%$ of the respondents practiced farming as their primary occupation while $17 \%$ trading as their primary occupation. $11 \%$ were civil servants and also $11 \%$ were artisans. The respondents are actively engaged in farming as their primary occupation. This shows that Nigeria is an agrarian country with over $75 \%$ of the people are into agriculture.

About $8 \%$ of the respondents were engaged in trading while $31 \%$ of them had farming as their secondary occupation. This shows that farming is perceived as a major occupation. This is in line with [7] who found out that farmer in the study area engaged in other occupation. Findings from the Table below reveal that $5 \%$ of the respondents had farming experience below 5 years, $21 \%$ had farming experience between 6 and 10 years, also $21 \%$ had farming experience between 11 and 15 years. $28 \%$ of the respondents had farming experience between 16 and 20 years while $12 \%$ had farming experience between 21 and 25 years. Lastly $7 \%$ of the respondents had experience in farming between 26 and 30 years, $7 \%$ had farmed for more than 30 years. The mean farming experience of the respondents was 17.0. This is in support of [7] who found out that majority of farmers in Ondo state has farming experience of between 11-20 years.

Results from Table below show that $11 \%$ of the respondents' monthly income was less than $\$ 30,000$ while another $11 \%$ earned between $\$ 31000$ and $\$ 40,000$ per month. $22 \%$ earned between $\$ 1,000$ - $\$ 50,000,21 \%$ earned between $\$ 51,000$ - $60000,16 \%$ earned between $\$ 61,000$ $\$ 70,000,16 \%$ earned between $\$ 71,000$ - $\$ 80,000$ and $19 \%$ of the respondents earned above $\$ 80000$. The average monthly income of the respondents was $\$ 58,209$ of which about $65 \%$ of the respondents earned as their monthly income. This depicts that the respondents earn above the fixed minimum wage of 18,000 in Nigeria. This could equally encourage youths to go into farm production. Results from Table 1 show that $59 \%$ of the respondents belong to certain crop societies while $41 \%$ of the respondents are not members of crop societies. Findings have shown that farmers tend towards adoption more when they belong to crop societies or farmer groups. This is not in support with [13] who concluded that membership to farmer groups does not necessarily lead to adoption of technologies. 
Table 1. Distribution of Respondents according to Socio-Economic Characteristics $(N=86)$.

\begin{tabular}{|c|c|c|c|}
\hline $\begin{array}{l}\text { Socio-economic } \\
\text { characteristics }\end{array}$ & Frequency & Percentage (\%) & Mean \\
\hline \multicolumn{4}{|l|}{ Sex } \\
\hline Male & 63 & 73.0 & \\
\hline Female & 23 & 26.0 & \\
\hline \multicolumn{4}{|l|}{ Age (years) } \\
\hline Below 40 & 16 & 19.0 & \\
\hline $41-45$ & 13 & 15.0 & 51.1 \\
\hline $46-50$ & 10 & 11.0 & \\
\hline $51-55$ & 19 & 22.0 & \\
\hline $56-60$ & 8 & 9.0 & \\
\hline Above 60 & 20 & 23.0 & \\
\hline \multicolumn{4}{|l|}{ Marital status } \\
\hline Single & 7 & 8.0 & \\
\hline Married & 66 & 77.0 & \\
\hline Divorced & 4 & 5.0 & \\
\hline Separated & 3 & 4.0 & \\
\hline Widowed/widower & 6 & 7.0 & \\
\hline \multicolumn{4}{|l|}{ Religion } \\
\hline Christianity & 59 & 69.0 & \\
\hline Islam & 26 & 30.0 & \\
\hline Others & 1 & 1.0 & \\
\hline \multicolumn{4}{|l|}{ Level of education } \\
\hline no formal education & 21 & 24.0 & 1.093 \\
\hline Primary & 41 & 48.0 & \\
\hline Secondary & 19 & 22.0 & \\
\hline Tertiary & 5 & 6.0 & \\
\hline \multicolumn{4}{|l|}{ Household size } \\
\hline below 3 & 9 & 11.0 & 5.00 \\
\hline $4-6$ & 56 & 65.0 & \\
\hline Above 6 & 21 & 24.0 & \\
\hline \multicolumn{4}{|l|}{ Primary occupation } \\
\hline Farming & 53 & 62.0 & \\
\hline Trading & 15 & 17.0 & \\
\hline civil servant & 9 & 11.0 & \\
\hline Artisan & 9 & 11.0 & \\
\hline \multicolumn{4}{|l|}{ Secondary occupation } \\
\hline Nil & 52 & 61.0 & \\
\hline Trading & 7 & 8.0 & \\
\hline Farming & 27 & 31.0 & \\
\hline \multicolumn{4}{|l|}{ Farming experience } \\
\hline Below 5 & 4 & 5.0 & 17.0 \\
\hline $6-10$ & 18 & 21.0 & \\
\hline $11-15$ & 18 & 21.0 & \\
\hline $16-20$ & 24 & 28.0 & \\
\hline $21-25$ & 10 & 12.0 & \\
\hline $26-30$ & 6 & 7.0 & \\
\hline Above 30 & 6 & 7.0 & \\
\hline \multicolumn{4}{|l|}{ Monthly income } \\
\hline below 30000 & 9 & 11.0 & \\
\hline $31000-40000$ & 9 & 11.0 & 58209 \\
\hline $41000-50000$ & 19 & 22.0 & \\
\hline $51000-60000$ & 18 & 21.0 & \\
\hline 61000-70000 & 14 & 16.0 & \\
\hline 71000-80000 & 1 & 1.0 & \\
\hline Above 80000 & 16 & 19.0 & \\
\hline \multicolumn{4}{|l|}{ Crop society } \\
\hline No & 35 & 41.0 & \\
\hline Yes & 51 & 59.0 & \\
\hline
\end{tabular}

Source: Field survey, 2018.

\subsection{Types of ICT Tools by Farmers to Get Information}

Results in Table 2 show that $3 \%$ of the respondents made use of mobile phone only to get agricultural related information. This is not in line with the findings of [8] who found out that majority farmers make use of mainly mobile phone to get agricultural related information. Results in Table 2 show that $47 \%$ of the respondents made use of only radio to get agricultural related information. This can be because the radio is accessible and readily available. This is in line with the findings of [14] who found out that farmers have access to radio. Findings in Table 2 show that $6 \%$ of the respondents made use of only internet to get agricultural related information. This can be because the internet requires training and high cost of internet access. Results the Table below shows that $15 \%$ of the respondents made use of only television to get agricultural related information. This might be because of electricity or high cost of getting a television set. This is not in line with the findings of [14] who found out that majority of the farmers make use of television to get agricultural information. The Table shows that $33 \%$ of the respondents made use of mobile phone and radio to get agricultural related information while $12 \%$ of the respondents made use of television and radio to get agricultural related information. Results in Table 2 show that $4 \%$ of the respondents made use of mobile phone and internet to get agricultural related information while just $2 \%$ of the respondents made use all of the above listed ICT tools to get agricultural related information.

Table 2. Distribution of the kind of ICT tools used by farmers to get information $(N=86)$.

\begin{tabular}{lll}
\hline ICT Tool & Frequency & Percentage (\%) \\
\hline mobile phone & 3 & 3.5 \\
Radio & 40 & 47.0 \\
Internet & 5 & 6.0 \\
Television & 13 & 15.0 \\
mobile and radio & 28 & 33.0 \\
television and radio & 10 & 12.0 \\
mobile and internet & 3 & 4.0 \\
all of the above & 2 & 2.0 \\
\hline
\end{tabular}

Source: Field survey, 2018.

\subsection{Frequency of Utilization of ICT Tools in Accessing Agricultural Information}

Research findings from Table 3 reveals that the ICT tools that were highly utilized by respondents were radio $(\overline{\mathrm{x}}=2.80)$ and use of mobile phone $(\overline{\mathrm{x}}=1.61)$. This indicates that Extension agents can make use of these services to disseminate information to farmers due to its high utilization of these services. This is in support of [14] who found out that mobile phone was regarded as the most frequently used ICT tool among the farmers using it very frequently. While the following services had a low utilization by the respondents; accessing internet $(\overline{\mathrm{x}}=0.21)$, television $(\bar{x}=1.40)$ and all the ICT tools combined $(\bar{x}=0.08)$, The low utilization of these services can be attributed to low usage of internet enabled phones, lack of access to other ICT tools, network coverage, affordability of electricity, low interest in utilizing the ICT tool to get agricultural information. 
Table 3. Distribution of the frequency of usage of ICT tools $(N=86)$.

\begin{tabular}{|c|c|c|c|c|c|c|c|c|c|c|}
\hline \multirow[t]{2}{*}{ ICT tool } & \multicolumn{2}{|c|}{ Frequently } & \multicolumn{2}{|c|}{ Occasionally } & \multicolumn{2}{|l|}{ Rarely } & \multicolumn{2}{|c|}{ Never } & \multirow{2}{*}{$\begin{array}{l}\text { Mean } \\
\overline{\mathbf{x}}\end{array}$} & \multirow{2}{*}{$\begin{array}{l}\text { Level of } \\
\text { utilization }\end{array}$} \\
\hline & Freq. & $\%$ & Freq. & $\%$ & Freq. & $\%$ & Freq. & $\%$ & & \\
\hline Mobile & 19 & 22.1 & 21 & 24.4 & 39 & 45.3 & 7 & 8.1 & 1.61 & high \\
\hline Internet & 3 & 3.5 & 1 & 1.2 & 7 & 8.1 & 75 & 87.2 & 0.21 & low \\
\hline Television & 5 & 5.8 & 30 & 34.9 & 45 & 52.3 & 6 & 7.0 & 1.40 & Medium \\
\hline Radio & 71 & 82.6 & 12 & 14.0 & 2 & 2.3 & 1 & 1.2 & 0.94 & high \\
\hline All above & 1 & 1.2 & 1 & 1.2 & 2 & 2.3 & 82 & 95.3 & 0.08 & low \\
\hline
\end{tabular}

Source: Field survey, 2018. Utilization of ICT tools "High utilization; $\overline{\mathrm{x}} \leq 2.0$ ", "Medium utilization; $\overline{\mathrm{x}} \leq 1.4$ " "Low utilization; $\overline{\mathrm{x}} \leq 0.4$ ".

\subsection{Benefits of Farmer.ng Market Solution Technology to Farmers'Business}

Findings from Table 4 shows that the respondents in the study areas strongly agreed to some of the benefit statements of the use of farmers.ng market technology. The respondents strongly agreed that the Usage of the technology helps to know when to sell produce; the mean score $(\bar{x}=2.53)$ indicates this fact. About $34 \%$ of the respondents indicated that they are undecided about the technology's ability in helping them to know when to sell farm produce due only a few of them making use of the technology already. Also the respondents were undecided about the usefulness of the technology to reduce risks of wastage, the mean score $(\overline{\mathrm{x}}=2.92)$ categorizes the respondents response as undecided, also they were undecided about the ability of technology to increase farmer level of engagement with market place. The mean score $(\overline{\mathrm{x}}=3.67)$ indicates that they are undecided, establish link with new customers the mean score $(x=2.93)$ indicates that they are undecided about the technology's ability to establish link with new customers, the respondents were also undecided about the ability of the technology to ensure quick and easy access to market and product, the mean score $(\bar{x}=2.92)$ affirms this fact, the respondents were also undecided about the technology's ability helps to maximize their profit. The mean score $(\overline{\mathrm{x}}=3.02)$ indicated this fact. While the respondents agreed to the following benefit statement of the usage of Farmer.ng Market Solution Technology: the respondents agreed that the technology gave them the knowledge of price produce with the mean score $(\bar{x}=4.0)$ which categorizes their response as agree, they agreed that the technology gives bargaining power, they also agreed that the technology gave easy access to accurate and timely information and gave cheaper and faster generation of information. The mean scores $(\overline{\mathrm{x}}=4.0)$ which indicated that they agreed to the benefits listed in Table $4,56 \%$ of the respondents believed that the use of Farmers.ng Market Solution Technology gives them knowledge of price of produce, $56 \%$ of the respondents believed that the use of Farmers.Ng Market Solution Technology gives them bargaining power, $11 \%$ of the respondents believed that the technology gives them easy access to accurate and timely information and $15 \%$ of the respondents believed that the use of the technology gives them cheaper and faster generation of information.

Table 4. Distribution of the Usefulness of Farmer.ng Market Solution Technology to Farmers'business $(N=86)$.

\begin{tabular}{|c|c|c|c|c|c|c|c|}
\hline \multirow{2}{*}{$\begin{array}{l}\text { Usage or benefits of farmers.ng market } \\
\text { technology }\end{array}$} & \multicolumn{5}{|c|}{ Frequency } & \multirow{2}{*}{$\operatorname{Mean} x^{-}$} & \multirow{2}{*}{ Remarks } \\
\hline & SA & $\mathbf{A}$ & $\mathbf{U}$ & D & SD & & \\
\hline helps to sell produce & 2 & 4 & 34 & 44 & 2 & 2.53 & Undecided \\
\hline knowledge of price produce & 8 & 56 & 17 & 4 & 1 & 4.0 & Agree \\
\hline connection to potential customer & 2 & 15 & 45 & 22 & 2 & 2.92 & Undecided \\
\hline reduces risk of wastage & 1 & 4 & 57 & 21 & 3 & 3.67 & Undecided \\
\hline gives bargaining power & 5 & 56 & 18 & 6 & 1 & 4.0 & Agree \\
\hline increase farmer engagement with market place & - & 1 & 2 & 60 & 23 & 2.78 & undecided \\
\hline quick and easy access to market & - & 1 & 9 & 58 & 18 & 2.92 & Undecided \\
\hline easy access to accurate and timely information & - & 11 & 58 & 14 & 3 & 4.0 & Agree \\
\hline cheaper and faster generation of information & - & 15 & 50 & 18 & 3 & 4.0 & Agree \\
\hline helps to maximize profit & 1 & 15 & 54 & 13 & 3 & 3.02 & undecided \\
\hline
\end{tabular}

Source: Field survey, 2018. Means calculated from a scale of: 5=strongly agree (SA), 4=Agree (A), 3=Undecided (U), 2=Disagree (D), 1=strongly disagree (SD).

\subsection{Effect of Utilization of Farmers.ng Technology on Income of Respondents}

Results from Table 5 indicated that the Farmers.ng Market Solution Technology had no effects on the income of the respondents; the mean score $(\overline{\mathrm{x}}=0.21)$ indicates that the technology had no effect on their profit, improved earnings $(\bar{x}=0.4)$ and increase in income $(\bar{x}=0.29)$. There was no effect on their income due to the following: only $16 \%$ of the respondents had made sales through the platform $(\bar{x}=0.16)$ this could be due to lack of reinforcement from the organization or lack of interest in the use of ICT. Eighty $(80 \%)$ indicated that the price is not favourable for them to make more profit, this may be due to the little difference in the profit margin they get from their local sale and sale through the technology, only $15 \%$ had control of the pricing of the platform and majority (69\%) of the respondents had no 
control over the pricing of the platform because the organization sent the prospective selling price of farm produce to the farmers.

Table 5. Distribution of the Effect of Utilization of Farmers.ng Technology on Income of Respondents $(N=86)$.

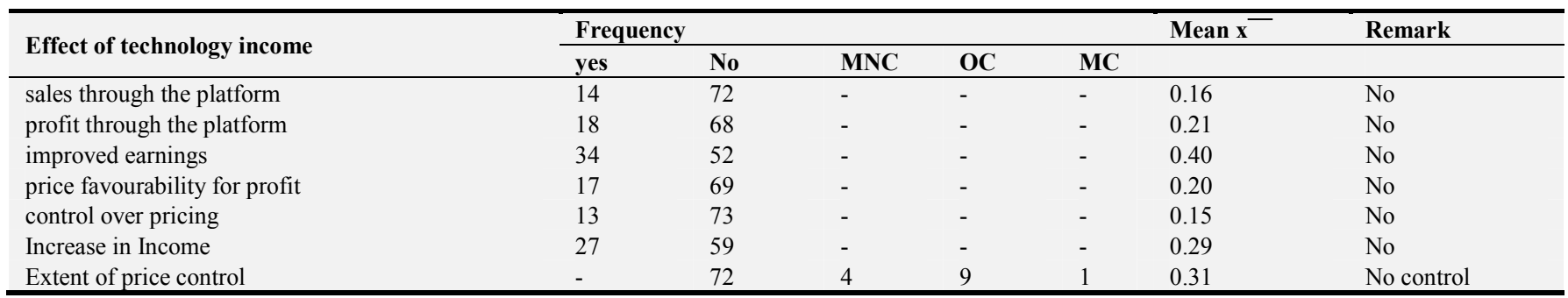

Source: Field survey, 2018. Means calculated from a scale of: $1=y e s, 0=$ no Mean $(\overline{\mathrm{x}})=0.5$ and also, $0=$ no control, $1=$ Minimum control $(\mathrm{MNC}), 2=\mathrm{Optimum}$ control (OC), 3=Maximum control $(\mathrm{MC})$. Mean $(\overline{\mathrm{x}})=2.0$.

\subsection{Assessments of Behaviour and Attitude of Farmers to the Usage of Farmers.ng Technology}

Findings in Table 6 reveal that $16 \%$ of the respondents used the technology to sell, while $85 \%$ used the information from technology to bargain. This finding is in support [14] who found out that farmers receive and make use of information gotten from ICT tools mostly mobile phones. About $20 \%$ of the respondents often used the technology, $83 \%$ of the respondent indicated that they will use the technology in the future, $81 \%$ of them indicated that they will adopt a similar technology in the future while $80 \%$ agreed that they will continue the usage of the technology, 94\% agreed that ICT can transform agriculture.

Table 7 indicated that only $16 \%$ of the respondents fully adopted the farmers.ng market solution technology which means they used the technology to sell their farm produce and bargained with the price information sent to them while $15 \%$ had not adopted the technology. $67 \%$ of the respondents partially adopted the technology which means they only made use of the price information sent to them by the organization to bargain with their prospective customers. Majority (85\%) of the respondents used the information provided by the technology to bargain, this indicates that majority adopted the information providing aspect of the technology and this indicates partial adoption. Results from Table 8 show that the respondents had very good thought about the technology. The mean score $(\bar{x}=2.30)$ indicated that the thought of the respondents are very good toward the technology also they indicated their very good thought about ability of the technology to easily get them information as indicated by the mean score $(\overline{\mathrm{x}}=2.20)$. The results also indicated that the respondents had good remark about the rate of operation of the technology as indicated by the mean score $(\bar{x}=2.00)$, the respondents had good remark about extent of help to their business as indicated by the mean score $(\bar{x}=1.47)$, the respondents had good remark about simplicity of the technology as indicated by the mean score $(\overline{\mathrm{x}}=1.72)$, the respondents had good remark about relevance to market need as indicated by the mean score $(\bar{x}=1.80)$, the respondents had good remark about performance of technology in meeting needs as indicated by the mean score $(\bar{x}=1.80)$, also the respondents had good trust in the technology as indicated by the mean score $(\bar{x}=1.13)$. Although, the respondents have fair remark about the ease of getting customer through the technology as indicated by the mean score $(\bar{x}=1.0)$ and the relevance of the technology in getting trusted customers as indicated by the mean score $(\overline{\mathrm{x}}=1.0)$. This implies that the farmers have formed a favourable attitude towards the technology. The findings of the present study are in line with the results obtained [17].

Table 6. Distribution of the Assessment of Behaviour and Attitude of Farmers to the Usage of Farmers.ng Technology $(N=86)$.

\begin{tabular}{|c|c|c|c|}
\hline $\begin{array}{l}\text { Attitude and behaviour of } \\
\text { farmers to the usage of } \\
\text { farmers.ng technology }\end{array}$ & Frequency & $\begin{array}{l}\text { Percentage } \\
(\%)\end{array}$ & Mean \\
\hline \multicolumn{4}{|l|}{ Usage of technology to sell } \\
\hline Yes & 14 & 16.0 & 0.16 \\
\hline No & 72 & 84.0 & \\
\hline \multicolumn{4}{|c|}{$\begin{array}{l}\text { Usage of technology information to } \\
\text { bargain }\end{array}$} \\
\hline Yes & 73 & 85.0 & 0.85 \\
\hline No & 13 & 15.0 & \\
\hline \multicolumn{4}{|c|}{ Frequency of usage of technology } \\
\hline Never & 28 & 33.0 & 0.90 \\
\hline Rarely & 41 & 48.0 & \\
\hline Often & 17 & 20.0 & \\
\hline \multicolumn{4}{|l|}{ Usage in the future } \\
\hline Yes & 71 & 83.0 & 0.83 \\
\hline No & 15 & 18.0 & \\
\hline Adoption in the future & 70 & 81.0 & 0.81 \\
\hline Yes & 16 & 19.0 & \\
\hline \multicolumn{4}{|l|}{$\begin{array}{l}\text { No } \\
\text { continued usage of technology }\end{array}$} \\
\hline Yes & 68 & 79.0 & 0.80 \\
\hline No & 18 & 21.0 & \\
\hline \multicolumn{4}{|c|}{ Recommendation to other farmers } \\
\hline Yes & 83 & 97 & 0.96 \\
\hline No & 3 & 3.0 & \\
\hline \multicolumn{4}{|l|}{$\begin{array}{l}\text { ICT in transformation of } \\
\text { agriculture }\end{array}$} \\
\hline Agree & 81 & 94.0 & 1.07 \\
\hline Disagree & 4 & 5.0 & \\
\hline Undecided & 1 & 1.0 & \\
\hline
\end{tabular}

Source: Field survey, 2018. 
Table 7. Distribution of the Adoption of Technology by Respondents (N=86).

\begin{tabular}{llll}
\hline Adoption of the technology & Frequency & Percentage (\%) & Mean $(\overline{\mathbf{x}})$ \\
\hline non-adoption & 13 & 15.0 & 2.01 \\
partial adoption & 59 & 67.0 & \\
full adoption & 14 & 16.0 & \\
\hline
\end{tabular}

Source: Field survey, 2018. Mean $(\overline{\mathrm{x}})=1.5$.

Table 8. Distribution of the Attitude and Behaviour of the Respondents towards the Usage of the Farmers.ng Technology (N=86).

\begin{tabular}{|c|c|c|c|c|c|c|c|}
\hline \multirow{2}{*}{ Attitude and behaviour towards technology } & \multicolumn{5}{|c|}{ Frequency } & \multirow{2}{*}{$\operatorname{Mean} \overline{\mathbf{x}}$} & \multirow{2}{*}{ Remarks } \\
\hline & $\mathbf{E}$ & VG & GD & FR & $\mathbf{P}$ & & \\
\hline thought of market solution technology & 3 & 34 & 33 & 16 & - & 2.30 & Very good \\
\hline rate the operation of the technology & 5 & 15 & 40 & 23 & 3 & 2.00 & Good \\
\hline extent of help to business & 2 & 15 & 18 & 37 & 14 & 1.47 & Good \\
\hline Simplicity & 3 & 18 & 31 & 20 & 14 & 1.72 & Good \\
\hline ease in getting information & 10 & 26 & 25 & 22 & 3 & 2.20 & Very good \\
\hline ease in getting customers & 2 & 6 & 21 & 19 & 38 & 1.00 & Fair \\
\hline relevance in getting trusted customers & - & 9 & 16 & 30 & 31 & 1.00 & Fair \\
\hline performance of tech in meeting needs & 3 & 23 & 25 & 24 & 11 & 1.80 & Good \\
\hline Trust in the technology & - & 7 & 28 & 20 & 31 & 1.13 & Good \\
\hline
\end{tabular}

Source: Field survey, 2018. Means calculated from a scale of: 4=excellent (E), 3=Very good (VG), 2=GD (U), 1=Fair (F), $0=$ Poor (P). Mean $(\bar{x})=2.0$.

\subsection{Constraints to the Usage of Farmers.ng Technology}

The Results from Table 9 indicates that the respondents perceive; network connection, complexity of the technology, unfavourable price for profit, and high cost of ICT, lack of interest in ICT, lack of awareness of the benefit and language barrier as minor constraints to the usage of farmers.ng technology. This was concluded from the mean score of each of these constraints which were less than or equal to 1.5 ( $\overline{\mathrm{x}} \leq$
1.5). The respondents also indicated that inadequate training by facilitators; lack of reinforcement from facilitators, lack of education to operate the technology and lack of ICT knowledge were the major constraints to the usage of farmers.ng market solution technology. This conclusion was made due to the mean score of each of the above named constraints which is greater than $1.5(\overline{\mathrm{x}} \geq 1.5)$.

Table 9. Distribution of the Constraints to the usage of Farmers.ng Technology among the Respondents $(N=86)$.

\begin{tabular}{|c|c|c|c|c|c|}
\hline Constraints & MC & MNC & NC & Mean $(\overline{\mathbf{x}})$ & Remarks \\
\hline Network connection & 8 & 78 & - & 1.00 & Minor constraint \\
\hline Complexity of technology & 6 & 22 & 58 & 0.95 & Minor constraint \\
\hline Inadequate training by facilitators & 16 & 25 & 45 & 1.66 & Major constraint \\
\hline Lack of reinforcement from facilitators & 23 & 32 & 31 & 2.00 & Major constraint \\
\hline Unfavorable price for profit & 8 & 13 & 65 & 1.34 & Minor constraint \\
\hline Lack of education to operate the technology & 10 & 21 & 55 & 1.50 & Major constraint \\
\hline No interest in ICT & 7 & 17 & 62 & 1.36 & Minor constraint \\
\hline Lack of awareness of benefits & 1 & 4 & 81 & 1.00 & Minor constraint \\
\hline Language Barrier & - & 3 & 83 & 1.00 & Minor constraint \\
\hline High cost of ICT & 3 & 8 & 75 & 1.16 & Minor constraint \\
\hline
\end{tabular}

Source: Field survey, 2018. Means calculated from a scale of: 2=Major Constraint (MC).

$1=$ Minor Constraint $(\mathrm{MNC}), 0=\operatorname{Not}$ a Constraint $(\mathrm{NC})$. Mean $(\overline{\mathrm{x}})=1.5$.

Hypothesis testing

10. Relationship between selected socio-economic characteristics and the adoption of the market solution technology.

$\mathrm{H}_{\mathrm{O} 1}$ : There is no significant relationship between adoption of the market solution technology and socioeconomic characteristics of the respondents.

The regression analysis is used to determine the cause and effect relationship between a dependent variable and set of independent variable. The correlation coefficient $(R)$ is calculated 0.64 , i.e. the correlation between the dependent variable (adoption of technology) and the independent variables. The coefficient of determination (R-square) is estimated to be 0.406 , which implies that about $41 \%$ of changes in adoption of technology are accounted for by the included independent variables. The remaining $59 \%$ is attributed to extraneous factors that are not included in the model. Though farming experience, income and level of education of the respondents exert positive effect on the adoption of the technology but do not have significant effect on the adoption of the technology.

The ANOVA Table provides the evidence of the fit of the model. Considering the $\mathrm{F}$ statistics and the corresponding level of significance i.e. $F(7,85)=7.628, p=0.000$, the model significantly predicts the dependent variable at $5 \%$. The estimates of regression coefficient reveal that sex, age, 
education household size and farming experience have a direct relationship with the adoption of the technology but only the estimated coefficient of age of farmer and household size were significant at $5 \%$. The equation of the model is thus displayed below;

Adoption of technology $=2.374+(-0.214) \mathrm{sex}+(-0.023)$ age of farmers $+(-0.088)$ household size +0.019 farming experience $+1.684 \mathrm{E}-6$ income $+(-0.029)$ crop society +0.115 level of education

Table 10. Relationship between selected socio-economic characteristics and the adoption of the market solution technology.

\begin{tabular}{|c|c|c|c|c|c|c|c|}
\hline \multicolumn{8}{|c|}{ Coefficients $^{a}$} \\
\hline \multirow{2}{*}{\multicolumn{2}{|c|}{ Model }} & \multicolumn{2}{|c|}{ Unstandardized Coefficients } & \multirow{2}{*}{$\begin{array}{l}\text { Standardized Coefficients } \\
\text { Beta }\end{array}$} & \multirow[b]{2}{*}{$\mathbf{t}$} & \multirow{2}{*}{ Sig. } & \multirow{2}{*}{ Remark } \\
\hline & & B & Std. Error & & & & \\
\hline \multirow{7}{*}{1} & (Constant) & 2.374 & .400 & & 5.941 & .000 & $\mathrm{~S}$ \\
\hline & Sex & -.214 & .128 & -.169 & -1.670 & .099 & NS \\
\hline & age of farmer & -.023 & .008 & -.441 & -2.803 & .006 & S \\
\hline & Household size & -.088 & .038 & -.233 & -2.297 & .024 & $\mathrm{~S}$ \\
\hline & farming experience & .019 & .010 & .278 & 1.926 & .058 & NS \\
\hline & crop society & -.029 & .109 & -.025 & -.263 & .793 & NS \\
\hline & level of education & .115 & .076 & .171 & 1.526 & .131 & NS \\
\hline \multicolumn{8}{|c|}{ a. Dependent Variable: adoption of technology } \\
\hline
\end{tabular}

Source: field survey, 2018. Significance at $\leq 0.05$.

\begin{tabular}{|c|c|c|c|c|}
\hline \multicolumn{5}{|c|}{ Regression Model Summary } \\
\hline Model & $\mathbf{R}$ & R Square & Adjusted R Square & Std. Error of the Estimate \\
\hline 1 & $.637^{\mathrm{a}}$ & .406 & .353 & .45321 \\
\hline
\end{tabular}

\begin{tabular}{|c|c|c|c|c|c|c|}
\hline \multicolumn{7}{|c|}{ ANOVA $^{b}$} \\
\hline Model & & Sum of Squares & Df & Mean Square & $\mathbf{F}$ & Sig. \\
\hline \multirow{3}{*}{1} & Regression & 10.967 & 7 & 1.567 & 7.628 & $.000^{\mathrm{a}}$ \\
\hline & Residual & 16.021 & 78 & .205 & & \\
\hline & Total & 26.988 & 85 & & & \\
\hline \multirow{3}{*}{\multicolumn{7}{|c|}{$\begin{array}{l}\text { a. Predictors: (Constant), level of education, crop society, household size, income, sex, farming experience, age of farmer } \\
\text { b. Dependent Variable: adoption of technology }\end{array}$}} \\
\hline & & & & & & \\
\hline \multicolumn{6}{|c|}{ DF- degree of freedom } & \\
\hline
\end{tabular}

11. Relationship between the attitude of the respondents and utilization of the market technology.

$\mathrm{H}_{\mathrm{O} 2}$ : There is no significant relationship between the attitude of the respondents and utilization of the market technology.

The PPMC (Pearson Product Moment Correlation) analysis results in Table 11 show that there was significant relationship between the attitude of the respondents (rvalue $=0.645, \mathrm{P} \leq 0.05$ ) and the utilization of the market technology. The null hypothesis is rejected and the alternate is accepted. This indicated that attitude of the farmers towards the technology affected the utilization of the market solution technology by the farmers.

Table 11. Relationship between the attitude of the respondents and utilization of the market technology.

\begin{tabular}{llll}
\hline Variable & r-value & Significance (p-value) & Decision \\
\hline Attitude and utilization of farmers.ng market technology & 0.645 & 0.000 & Significant \\
\hline
\end{tabular}

Tested at $5 \%$ level of significance.

\section{Conclusion}

Based on the findings of this study, it can be concluded that sex, age, marital status, level of education; total farming experience and membership of crop society of the respondents have effects on the adoption and utilization of the market technology. Results showed that majority (67\%) of the respondents partly adopted the Farmers.Ng Market Solution Technology. Based on the findings of this study, it can be drawn that the majority ( $85 \%$ ) of the respondents got and used the market information provided by the technology, only $16 \%$ of the respondents used the technology to sell their farm produce while a non-substantial percentage $(15 \%)$ of the respondents used the market information provided by the technology and sold their farm produce through it (This clearly explains the general partial adoption of the technology).

\section{Recommendation}

Based on the conclusion of this study, the following 
recommendations were made;

a. There is a need for national governments to partner with organizations such as farmers.ng in order facilitate sharing of agricultural related information, knowledge, experiences on different initiatives and projects on ICTs in Africa.

b. There is need to develop strategies for providing training and strengthening individuals, groups and communities' capacity in order to be conversant with the use of ICT in getting market information and in getting links to new customers.

c. The organization and other agriculturally oriented organizations should encourage small-scale farmers to operate in community groups because this accelerates adoption of technologies.

\section{References}

[1] Aina, L. O. ( 2007). 'Globalisation and small-scale farming in Africa: What roles for information centres?' In World Library and Information Congress: Seventy-third IFLA General Conference and Council. Durban, South Africa. Page 19-23.

[2] Anselme Bienvenu Adegbidi, 2012: Journal of Research in International Business and Management (ISSN: 2251-0028) Vol. 2 (11) pp. 261-272, November, 2012 Available online@http://www.interesjournals.org/JRIBM Copyright (C)2012 International Research Journals.

[3] Ayodele et al. 2016. Effects of Farmers' Socio-economic Characteristics on their Perception on Cassava Production in Ondo State, Nigeria. Asian Journal of Agricultural Extension, Economics \& Sociology 8 (4): 1-10.

[4] Farmers.ng market solution technology, 2016: https://techpoint.africa/2016/06/14/farmersng-is- connectingfarmers-to-customers/

[5] Fasina O. O. 2015. Determents of Radio Agricultural Programmes Listenership: A Case Study of Futa FM 93.1 Radio Station in Ondo State, Nigeria. Agricultural communications, 2015, 3 (1): 50-55.

[6] Fasina O. O. and Adekoya A. E. 2010. Personal characteristics predisposing children to agricultural involvement among the Yoruba's in South West Nigeria. KRE Journal Studies of Tribes and Tribals. 8: 115-120.

[7] Fawole W. O and M. A. Y. Rahji, (2016). Determinant of productivity among farmers in Ondo state of Nigeria. Asian Journal of Agricultural Extension, Economics and Sociology. $9(4) ; 1-7$.

[8] Kameswari, V. L. V., Kishore, D. and Gupta, V. (2011) ICTs for Agricultural Extension: A study in the Indian Himalayan region. The Electronic Journal on Information Systems in Developing Countries, 48 (3): 12. https://www.ejisdc.org/ojs2/index.php/ejisdc/article/view/847/ 372.

[9] Lightfoot, C. and Scheuermeier, U. 2007. 'Organizing the learning for rural marketing through linking local learners: How to improve smallholder farmers' links to markets'. Rural Development News 2: 30-4.

[10] Mafimisebi T. E. and Oguntade A. E. 2011. Health infrastructure inequality and rural urban utilization of traditional and orthodox medicine in farming households: a case study of Ekiti State Nigeria. Health management. INTECH Open Access Publisher, Croatia. pp: 25-32.

[11] Manda, P. A. 2002. 'Information and agricultural development in Tanzania: A critique'. Information Development 18 (3): $181-9$.

[12] Mawazo Magesa 2015: Linking Rural Farmers to Markets Using ICTs, CTA Working Paper 15/12| November, 2015.

[13] Mwaura F., 2014. Effect of farmer group membership on agricultural technology adoption and crop productivity in Uganda'. African Crop Science Journal. 22 (4): 917-927.

[14] Nakweya, 2013: Radio, mobile phones could boost African farm yields http://www.scidev.net/sub-saharanafrica/icts/news/radio-mobile-phones-could-boost-africanfarm-yields.html.

[15] National Bureau of Statistics. 2009. Social statistics in Nigeria Federal Republic of Nigeria. Page 418.

[16] Rao, N. H. 2007. 'A framework for implementing information and communication technologies in agricultural development in India'. Technological Forecasting \& Social Change 74: 491-518.

[17] Reddy P R and Reddy S J. 1997. Farm Broadcasts: Listening Behavior of Farmers, Harita Publishing House, Hyderabad. Pp $37-91$.

[18] Wole-Alo and Okunlola, 2015. Utilization of Modern Cassava Processing Technologies among Small holder Women Processors in Ondo state, Nigeria. Journal of Biology, Agriculture and Healthcare, 5 (12): 29-33. 